\title{
A Comparative Study of the Chemical Composition of the Essential oil from Eucalyptus globulus Growing in Dehradun (india) and Around the World
}

\author{
ARCHANA JOSHI ${ }^{1}$, ASHUTOSH SHARMA ${ }^{1}$, R.K. BACHHETI ${ }^{1 *}$ and D. P. PANDEY \\ 'Department of Applied Sciences, Graphic Era University, Dehradun India. \\ ${ }^{2}$ Department of Chemistry, Govt. P. G. College Uttarkashi, Uttarakhand India. \\ ${ }^{*}$ Corresponding author E-mail: rkbfri@ rediffmail.com \\ http://dx.doi.org/10.13005/ojc/320137
}

(Received: January 12, 2016; Accepted: March 16, 2016)

\begin{abstract}
Due to increasing use of natural products, essential oil are also in great demand in various field such as pharmaceutical, cosmetic and food industries. The aim of this study is to determine the chemical composition of essential oil of Eucalyptus globulus grown in Dehradun, India. A total of twenty seven compounds were identified from the essential oil, by Gas chromatography mass spectroscopy representing $100 \%$ of the total oil. The dominant compounds being Eucalyptol $(1,8-$ cineole) $54.79 \%$, â- pinene $18.54 \%$ á- pinene $11.46 \%$, â- eudesmol $4.68 \%$, á-phellandrene $2.06 \%$ Para cymene $1.60 \%$ and Gamma- eudesmol $1.20 \%$. Comparison of the literature on essential oil from Eucalyptus globulus around the world (seven countries) suggested eight compounds that were uniquely present only in Dehradun essential oil sample. Thus, the present study suggested that Eucalyptus globulus growing in Dehradun contains several volatile compounds that are not reported in other Eucalyptus globulus essential oil around the world.
\end{abstract}

Key words: Eucalyptus globulus, chemical composition, comparison.

\section{INTRODUCTION}

Due to awareness regarding the use of synthetic additives, people are now using natural essential oil in the various field such as food, drinks, toiletries and cosmetics ${ }^{1}$. Many reports available which shows the use of essential oil in food, pharmaceutical, aromatherapy, perfumes, antibacterial-antifungal agents, and to repel insect or protect stored products ${ }^{2-5}$. Plant essential oils are obtained from non-woody parts of the plant, particularly foliage, through steam or hydrodistillation. Main components of essential oil are hydrocarbons, aromatic derivatives, terpenes and their oxygenated derivatives (mono- and sesqui-terpenoids, alcohols and esters $)^{6,7}$. Essential oil has been cultivated for medicinal oil production in many parts of the world. Numbers of reports are available all around the world which shows the antibacteria| $\left.\right|^{8-11}$ and antioxidant of Eucalyptus Leaves ${ }^{12-16}$. Eucalyptus essential oil is 
extracted from Eucalyptus globulus of the Myrtaceae family and is also known as Tasmanian blue gum or blue gum. There are over 500 species of Eucalyptus trees, with tough long and narrow blue-green leaves, creamy white flowers and smooth pale bark ${ }^{17}$.

Eucalyptus has a long history in India. It was first planted around 1790 by Tippu Sultan, the ruler of Mysore, in his palace garden on Nandi hills near Bangalore. According to one version he received seed from Australia and introduced about 16 species $^{18}$. In India there are number of Eucalptus species available such as E. tereticornis, E. grandis, E. citriodora, E. globulus, and E. camaldulensis. There are various studies available on chemical composition and antimicrobial activity of essential oil of Eucalyptus of Indian origin ${ }^{19,20}$ but to the best of my knowledge, no report is available on the chemical constituents of Eucalyptus globulus leave essential oil grown in Dehradun, India.

\section{MATERIALS AND METHODS}

\section{Plant Material}

Leaves of Eucalyptus globulus were collected from Dehradun in the month of September, 2013. The species were identified by Dr. Sumer Chand Ex Scientist in Forest Research Institute (FRI) Dehradun, India.

\section{Description of the study area}

Dehradun is one of the oldest cities of Uttaranchal, situated in the foothills of the Great Himalayas. This is one of the 13 administrative districts of the state and is important for tourism point of view. The district is surrounded by the Himalayan Mountains in the north, Shivalik hills in the south, the river Ganga in the east, and the river Yamuna in the west. The two pristine rivers Ganga and Yamuna pass through the district.

The geographical area of the district is $3088.00 \mathrm{sq} . \mathrm{kms}$, lies between $30.19^{\circ} \mathrm{N}$ latitude and $78.04^{\circ} \mathrm{E}$ longitude. Average rainfall in the district is about $2073.3 \mathrm{~mm}$.

\section{Extraction of essential oil}

Freshly collected $100 \mathrm{~g}$ leaves were weighed and hydrodistilled for four hours for complete extraction of essential oil, using a commercial
Clevenger-type apparatus. The oil sample obtained from hydrodistillation was freed from moisture by adding anhydrous sodium sulfate and an absolute oil sample was obtained.

\section{Percentage yield of Oil}

The amount of extracted oil was determined and yield\% of the extracted oil from each sample on the basis of various eucalyptus leaves samples by using following formula:

$$
\text { Yield of oil }(\%)=\frac{\text { Weight of oil } x 100}{\text { Weight of Eucalyptus leaves }}
$$

\section{GC-MS Analysis of Essential oil}

The essential oil from leaves of Eucalyptus globulus was analyzed on GC-MS QP-2010 Plus (Shimadzu Company) using HP-5 MS column ( $30 \mathrm{~m}$ $x 0.25 \mathrm{~mm}$ internal diameter $\times 0.25 \mathrm{im}$ film thickness) which was coated by $5 \%$ phenyl $95 \%$ methyl poly siloxane stationary. The syringe was washed with $8 \mathrm{iL}$ of chloroform and $2 \mathrm{iL}$ essential oil solution in chloroform was injected through autosampler and analyzed with HP5 MS column. Column temperature was programmed as follows: 50 to $120^{\circ} \mathrm{C}$ at 20 , 120 to $150^{\circ} \mathrm{C}$ at $4{ }^{\circ} \mathrm{C} / \mathrm{min}, 150$ to $250^{\circ} \mathrm{C}$ at $20 \mathrm{oC} /$ min (10 min hold time) and 3.5 min solvent delay. The temperature of the injector was fixed to 260 ${ }^{\circ} \mathrm{C}$ and the detector (FID) to $270{ }^{\circ} \mathrm{C}$. Carrier gas was helium $(1 \mathrm{~mL} / \mathrm{min})$ with $69.8 \mathrm{kPa}$ and a split ratio of $100: 1$. The interface temperature was 280 ${ }^{\circ} \mathrm{C}$. The mass spectra were recorded in electron ionization mode at $70 \mathrm{eV}$ with scanning from 40 to $600 \mathrm{~m} / \mathrm{z}$ at $0.5 \mathrm{~s}$ and ion source temperature was set at $230{ }^{\circ} \mathrm{C}$. The percentage of each constituent in the oil was determined based on GC peak areas. The constituents of essential oil were identified by their retention index, MS Library search (NIST 08 and WILEY 8 libraries) and by comparison with the spectra and retention index data in the literature.

\section{RESULTS AND DISCUSSION}

Hydrodistillation of the E. globulus leaves yielded $1.1 \%$ of essential oil ( $w / w$, based on the fresh weight of the mature leaves). There are many literature reported for E. globulus where the essential oil yield was 1.9-2.7\% (w/w, based on the fresh weight of the young leaves) in Morocco ${ }^{21}$, $2.68 \%(\mathrm{w} / \mathrm{w}$, based on the fresh weight of the adult leaves) in Argentina ${ }^{22}$, and $1.05 \%$ in India ${ }^{8}$. 
The chemical composition of the E. globulus essential oil (Dehradun) is shown in Table 1. GC-MS analyses revealed the presence of twenty seven compounds representing $100 \%$ of the total oil. In these 27 compounds, some are sesquiterpenes, monoterpenes, oxygenated monoterpenes and oxygenated sesquiterpenes respectively. Eucalyptol (1, 8- cineole) $(54.79 \%)$, beta-pinene (18.54\%), alphapinene $(11.46 \%)$, beta-eudesmol $(4.68 \%)$, alpha- phellandrene $(2.06 \%)$, para-cymene $(1.60 \%)$ and gamma-eudesmol (1.20\%) are the main components (Table 1). Beta-eudesmol suppresses tumour growth through inhibition of tumour neovascularisation and tumour cell proliferation ${ }^{23}$.

Table 1 shows the list of different compounds obtained in the essential oil of E. globulus and compared to the previous results of the different

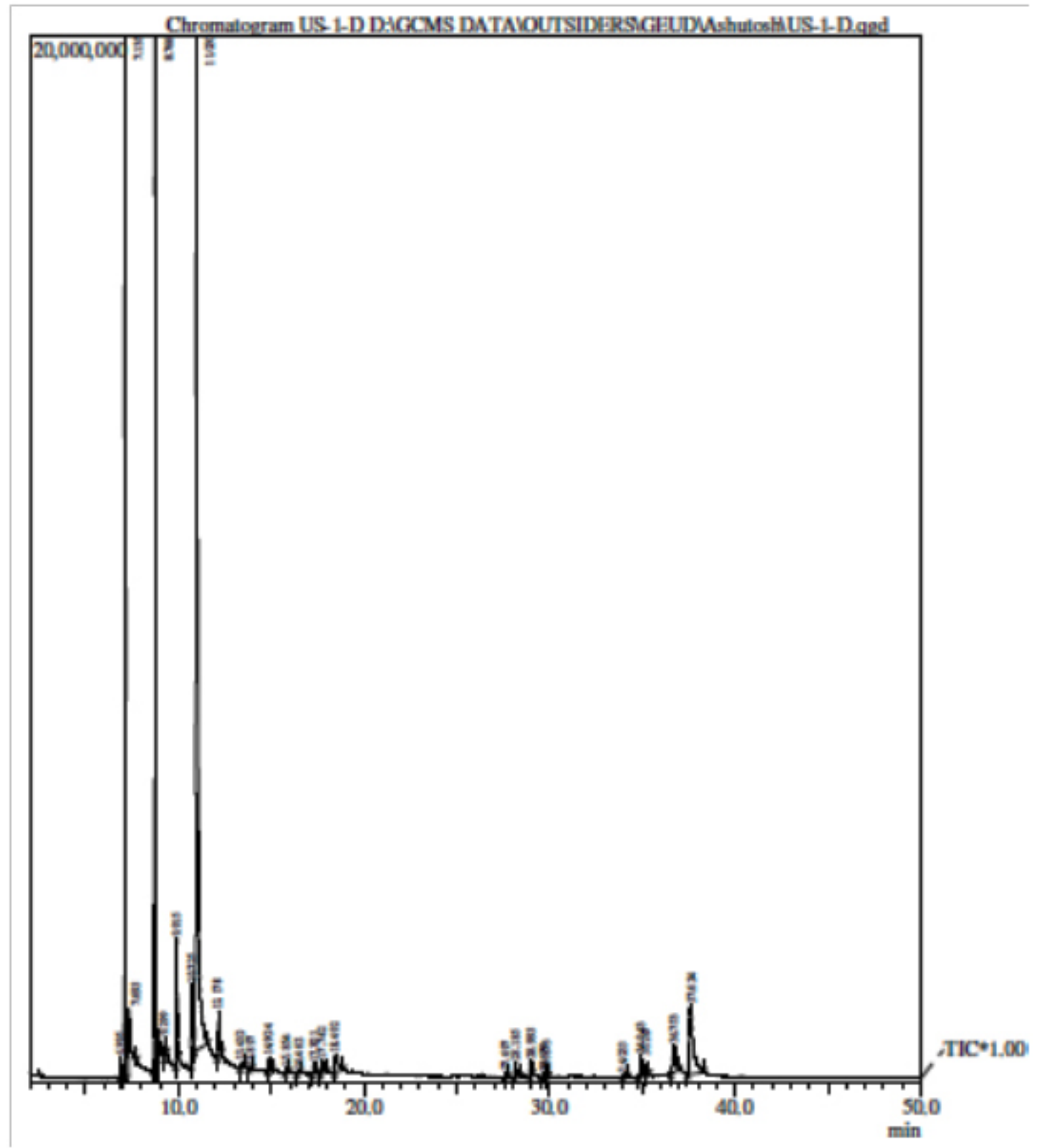

Fig.1: GC-MS chromatogram of Eucalyptus Globulus essential oil 


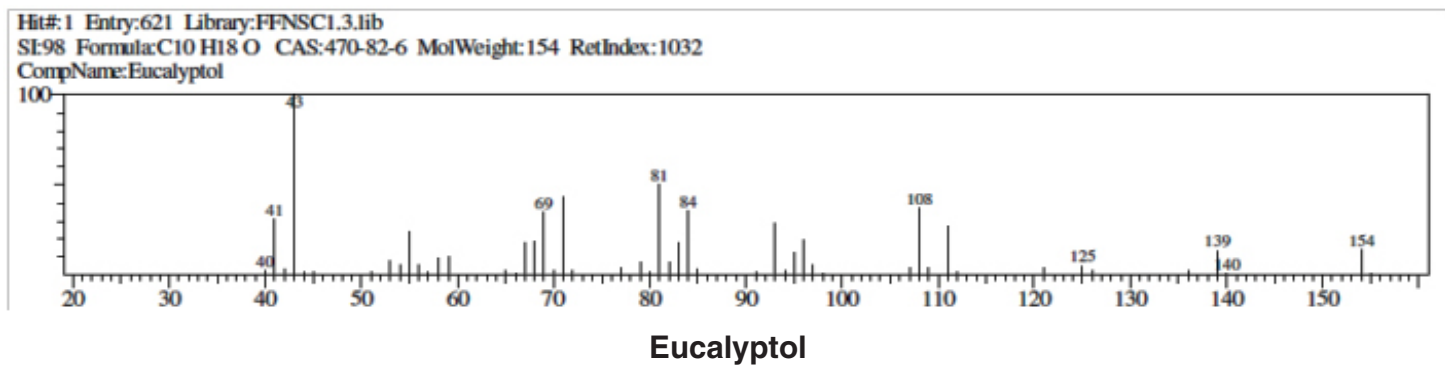

Hit\#:2 Entry:6297 Library:NIST05s.LB

SL97 Formula:C10H16 CAS:18172-67-3 MolWeight:136 RetIndex:943

CompName:Bicyclo[3.1.1] heptane, 6,6-dimethyl-2-methylene, (1S)- \$2(10)-Pinene, (1S,5S)-(-)-\$\$ (-).beta-Pinene \$\$ (-)-2(10)-Pinene \$\$ L-beta-pinene \$

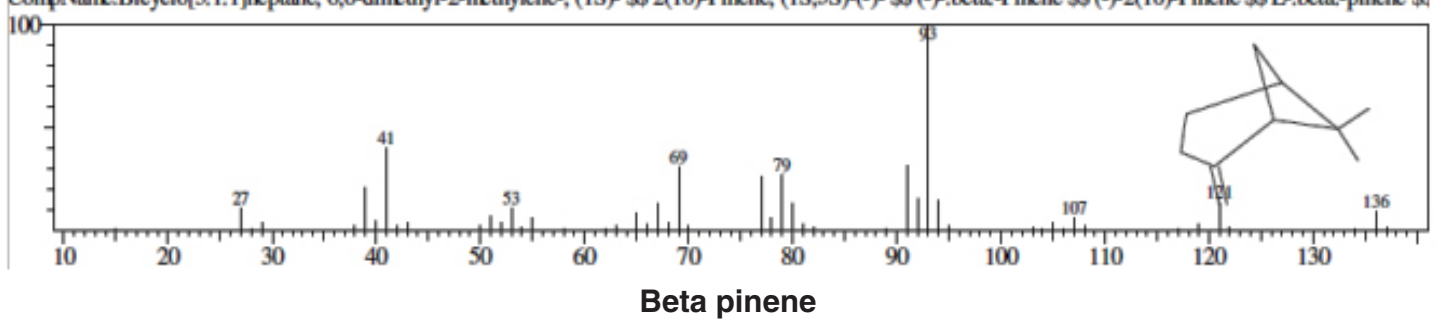

Hitt.23 Entry:6317 Library:NIST05s.UB

St:88 FormulaC10H16 CAS:7785-70-8 MolWeight:136 Rethdex:948

CompName: IR-alpha-Pinene \$\$ IR-alpha-Pinene \$\$ Bicyclo[3,1.1]hept-2-ene, 2, 6,6-trimethyl-, (IR)-\$\$2,6,6-Trimethylbicyclo[3,1.1]hept-2-ene \#\$\$

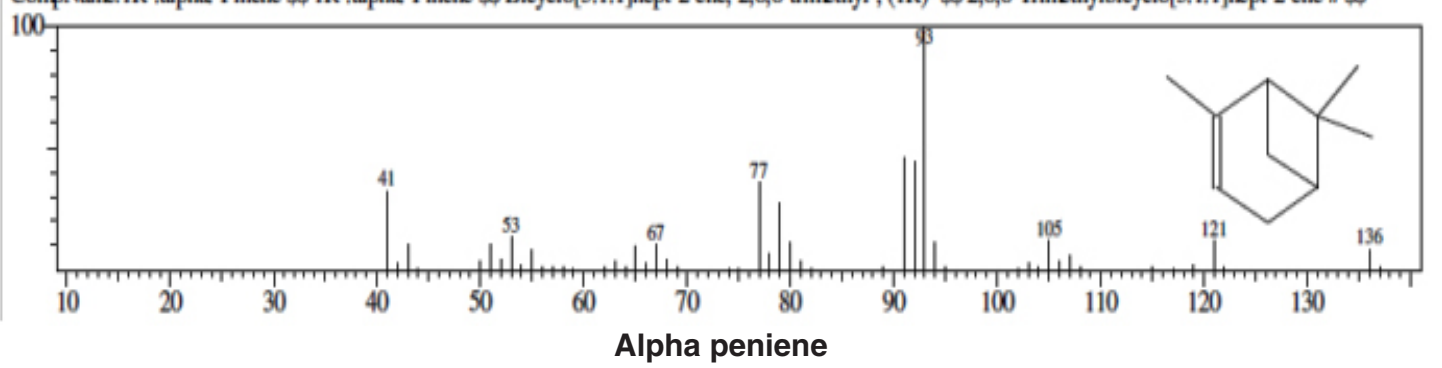

Hit\#:2 Entry:71 Library:SZTERP.LB

SI:91 Formula:C15 H26 O CAS:0-00-0 MolWeight:222 Retindex:0

CompName:EUDESMOL <BETA-> DB5-1993

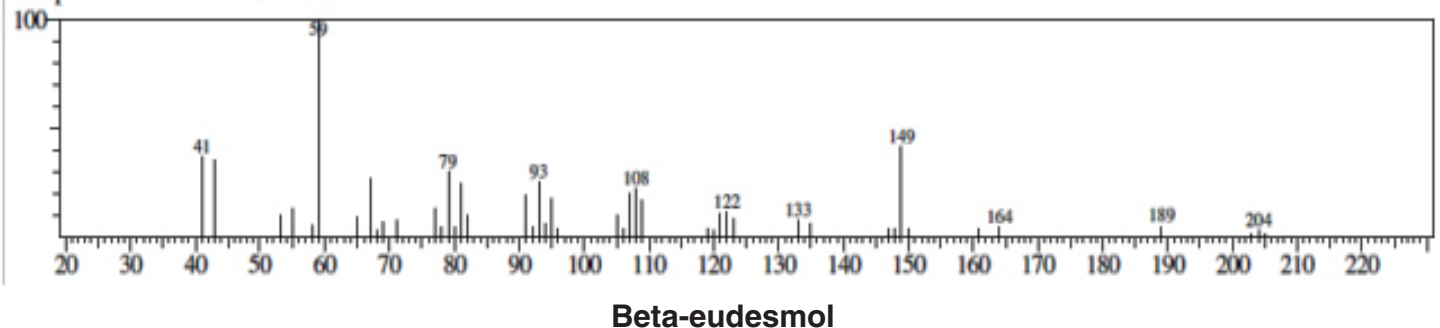

Beta-eudesmol 


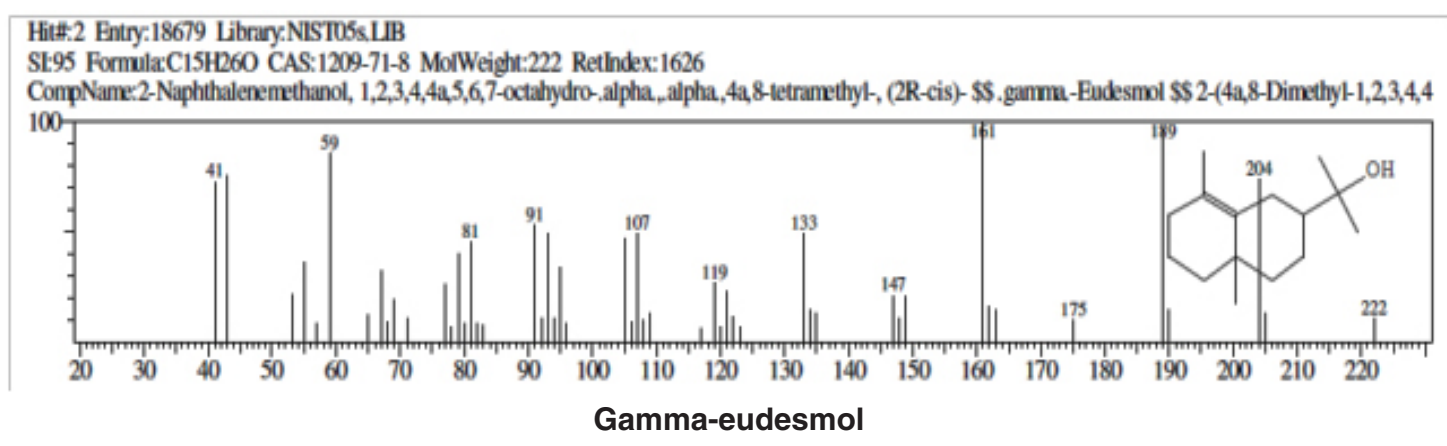

Hit\#:3 Entry:6312 Libraly:NIST05s.LB

SE95 FormulaC10H16 CAS:99-83-2 MolWeight:136 Retlndex:969

CompName.alpha-Phellandrene \$\$ 1,3-Cyclohexadiene, 2-methyl-5-(1-methylethyl)-\$\$ p-Menthadiene ((-) \$\$.alpha-Fellandrene \$\$ p-Mentha-1,5-diene \$\$

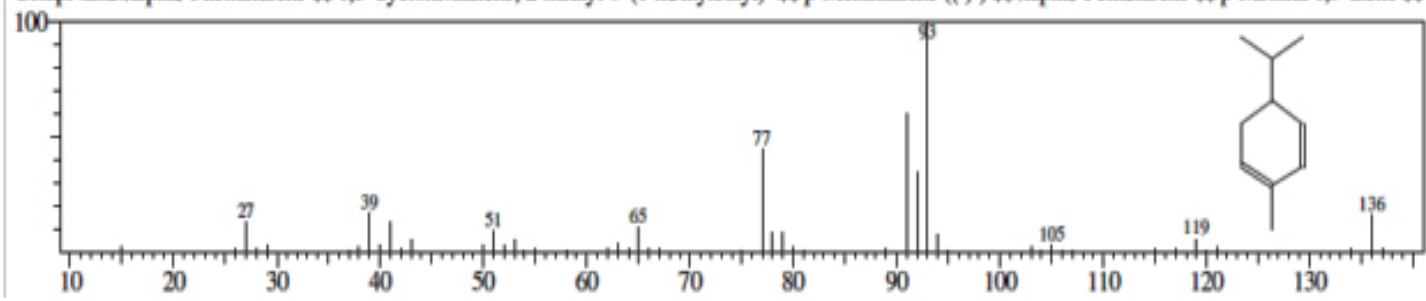

Alpha-phellandrene

Hit\#:20 Entry:165 Library:SZIERP.UB

SL:89 Formula:C10 H14 CAS:0-00-0 MolWeight:134 Retlndex:0

CompName:CYMENE $<$ PARA-> DB5-471

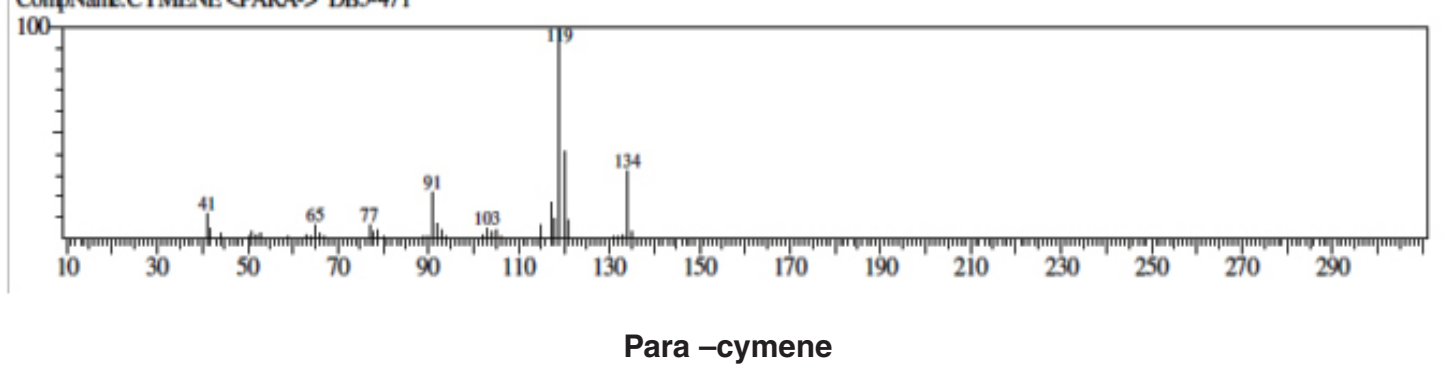

Fig. 2: Mass spectrum $(\mathrm{m} / \mathrm{z})$ of major components present in Eucalyptus globulus essential oil with peak report

countries. The list shows that eucalyptol percentage is maximum in Montengro (85.82\%) and minimum in Tunsia (43.18\%). Variation in chemical composition is due to different environmental, agronomic factors. The age and geoclimatic factors also effect the chemical composition of essential oil ${ }^{23}$. Betaeudesmol is present only in essential oil of two countries- India $4.68 \%$ and Ethiopia $0.10 \%$. Hence essential oil obtained from Dehradun can be a good source of Beta-eudesmol.
Table 1 also shows that there are 6 unique compounds in present study (Dehradun). These unique compounds are alpha-fenchyl alcohol $(0.27 \%)$, borneol $(0.27 \%)$, alpha-humulene $(0.07 \%)$, trans-caryophyllene $(0.09 \%)$, ledol $(0.03 \%)$ and gamma-eudesmol (1.20\%) respectively.

The dominant compounds being Eucalyptol (1, 8-cineole) 54.79 is the major component in all essential oil of all countries presented in table 1. Eucalyptol (1-8 cineole) is a cyclic ether with 
Table 1: Chemical composition of essential oil from Eucalyptus globulus (fresh leaves) from various Countries around the world

\begin{tabular}{|c|c|c|c|c|c|c|c|c|c|}
\hline $\begin{array}{l}\text { S. } \\
\text { No. }\end{array}$ & Compounds & $\begin{array}{l}\text { Present } \\
\text { Study } \\
\text { Dehradun } \\
\text { India }\end{array}$ & Nigeria & Algeria & Iran & Brazil & $\begin{array}{l}\text { Monte- } \\
\text { negro }\end{array}$ & Tunsia & Ethiopia \\
\hline 1. & Á-thujene & 0.26 & - & - & - & - & - & - & 0.07 \\
\hline 2. & Á-pinene & 11.46 & 4.16 & 24.60 & 9.30 & 4.15 & 7.16 & 13.61 & 23.79 \\
\hline 3. & Camphene & 0.12 & - & 0.117 & 23.1 & - & 0.05 & - & - \\
\hline 4. & Beta-Pinene & 18.54 & - & 0.217 & 2.70 & - & 1.10 & 0.74 & 1.01 \\
\hline 5. & Beta-myrcene & 0.30 & - & - & - & - & 1.52 & 0.00 & - \\
\hline 6. & Alpha-phellandrene & 2.06 & 2.20 & - & - & - & 0.55 & 0.22 & 0.05 \\
\hline 7. & Para-cymene & 1.60 & 8.10 & - & - & - & 0.05 & - & 0.57 \\
\hline 8. & Eucalyptol & 54.79 & - & 44.30 & 76.65 & 83.89 & 85.82 & 43.18 & 62.38 \\
\hline 9. & Gamma-terpinene & 0.97 & 17.01 & - & 0.63 & - & - & 0.36 & - \\
\hline 10. & Alpha-terpinolene & 0.15 & - & - & - & - & - & 0.50 & - \\
\hline 11. & Alpha-pinene epoxide & 0.04 & - & - & - & - & - & - & 0.07 \\
\hline 12. & Alpha fenchyl alcohol & 0.27 & - & - & - & - & - & - & - \\
\hline 13. & Trans-pinocarveol & 0.12 & - & - & - & - & - & 3.76 & - \\
\hline 14. & Camphene hydrate & 0.07 & - & - & - & - & - & - & 0.09 \\
\hline 15. & Borneol & 0.27 & - & - & - & - & - & - & - \\
\hline 16. & 4-terpineol & 0.54 & 23.46 & 0.2 & 0.37 & - & 0.49 & 0.40 & 0.59 \\
\hline 17. & Aplpha-terpineol & 0.86 & - & - & 1.96 & - & 0.14 & - & - \\
\hline 18. & Alpha-gurjunene & 0.10 & - & - & - & - & - & 1.33 & 0.35 \\
\hline 19. & Beta-caryophyllene & 0.40 & - & - & - & - & - & 0.81 & - \\
\hline 20. & Alloaromadendrene & 0.34 & - & - & 3.98 & - & - & - & - \\
\hline 21. & Alpha-humulene & 0.07 & - & - & - & - & - & - & - \\
\hline 22. & Trans-caryophyllene & 0.09 & - & - & - & - & - & - & - \\
\hline 23. & Epiglobulol & 0.09 & - & - & 0.04 & - & - & - & 0.21 \\
\hline 24. & Globulol & 0.58 & 2.52 & 7.30 & - & - & - & - & 1.68 \\
\hline 25. & Ledol & 0.03 & - & - & - & - & - & - & - \\
\hline 26. & Gamma-eudesmol & 1.20 & - & - & - & - & - & - & - \\
\hline 27. & Beta-eudesmol & 4.68 & - & - & - & - & - & - & 0.10 \\
\hline 28. & Apple oil & - & 5.55 & - & - & - & - & - & - \\
\hline 29. & Cis - sabinol & - & 3.11 & - & - & - & - & - & - \\
\hline 30. & Piperitone & - & 5.90 & - & - & - & - & - & - \\
\hline 31. & Pinanediol & - & 4.07 & - & - & - & - & - & - \\
\hline 32. & p-Cymen-7-ol & - & 6.39 & - & - & - & - & - & - \\
\hline 33. & Cycloprop(e) azulene & - & 1.23 & - & - & - & - & - & - \\
\hline 34. & Alpha- Selinene & - & 0.57 & - & - & - & - & - & - \\
\hline 35. & Menthane-1,2,3-triol & - & 4.41 & - & - & - & - & - & - \\
\hline 36. & Spathulenol & - & 8.94 & - & - & - & - & - & 0.41 \\
\hline 37. & Eudesmeneol & - & 2.38 & - & - & - & - & - & - \\
\hline 38. & Alpha-Campholenal & - & - & - & - & - & - & 0.20 & - \\
\hline 39. & Fenchol & - & - & - & - & - & - & - & - \\
\hline 40. & L-pinacarveol & - & - & - & - & - & - & - & - \\
\hline 41. & Caren-4-ol & - & - & - & - & - & - & - & - \\
\hline 42. & Alpha - Terpineol & - & - & 0.30 & - & - & - & 1.65 & 0.70 \\
\hline
\end{tabular}


43. Myrtenol

44. Cis-Carveol

45. Sabinene

46. Limonene

47. Cis-beta-Ocimene

48. Trans-Carveol

49. Alpha-terpineol acetate

50. Geranyl acetate

51. Isoledene

52. Isopulegol acetate

53. (-)-Cis-carvyl acetate

54. Beta-panasinsene

55. Beta-gurjunene

56. Aromadendrene

57. Alpha-guaiene

58. O-Cymene

59. Myrcene

60. P Cymene

61. Linalool

62. Cryptone

63. Alpha terpenyl acetate

64. Citronellol

65. Garaniol

66. Gamma Terpinene

67. Alpha Terpinene

68. Pinocarveol

69. Exo-2-

Hydroxycineole acetate

70. Viridiflorene

71. Veridiflorol

72. Endo Fenchol

73. Beta Cymene

74. Alpha Campholenal

75. Camphor

76. Pinocarvone

77. p-Cymen-8-ol

78. Carveol

79. Carvone

80. Pulegone

81. Beta-Fenchol

82. Bornyl Acetate

83. 4-Carene

84. Beta Caryophyllene

85. Aristolene

86. Beta-Selinene

87. Alpha-Humulene

88. Allo-Aromandendrene

89. Alpha-Selinene

90. Ledene

$\begin{array}{cccccc}- & 0.65 & - & - & - & - \\ 5.10 & 0.84 & 8.16 & 0.85 & - & - \\ - & 0.15 & - & - & - & - \\ - & 0.06 & - & - & - & - \\ - & 4.85 & - & - & - & 5.41 \\ - & 0.06 & - & - & - & - \\ - & 0.54 & - & - & - & - \\ - & 0.02 & - & - & - & - \\ - & 0.02 & - & - & - & - \\ - & 0.02 & - & - & - & - \\ - & 0.36 & - & - & - & - \\ 1.30 & 0.51 & - & - & 10.09 & 1.53 \\ - & 0.01 & - & - & - & - \\ - & - & 2.93 & - & - & - \\ - & - & - & - & - & 0.17 \\ 1.60 & - & - & - & - & - \\ 0.30 & - & - & 0.43 & - & - \\ 1.30 & - & - & - & - & - \\ 1.20 & - & - & - & - & 5.41 \\ 0.10 & - & - & - & - & - \\ 0.20 & - & - & - & - & - \\ - & - & - & 1.16 & - & - \\ - & - & - & 0.11 & - & - \\ - & - & - & 0.44 & - & - \\ - & - & - & - & - & 0.23 \\ - & & & & & - \\ - & - & - & - & - & 0.12 \\ - & - & - & - & - & 0.34 \\ - & - & - & - & 0.00 & - \\ - & - & - & - & 3.95 & - \\ - & - & - & - & 0.20 & - \\ - & - & - & - & 0.00 & - \\ - & - & - & - & 2.99 & - \\ - & - & - & - & 0.23 & - \\ - & - & - & - & 0.44 & - \\ - & - & - & - & 0.22 & - \\ - & - & - & - & 0.15 & - \\ - & - & - & - & 0.00 & - \\ - & - & - & - & 0.00 & - \\ - & - & - & - & 6.90 & - \\ - & - & - & - & 0.81 & - \\ - & - & - & - & 0.70 & - \\ - & - & - & - & 0.30 & - \\ - & - & - & - & 0.52 & - \\ - & - & - & - & 2.23 & - \\ - & - & - & - & 0.00 & - \\ - & - & - & - & 1.06 & -\end{array}$


Table 2: Compounds present uniquely in E. globulus essential oil (Dehradun sample)

\begin{tabular}{|c|c|c|}
\hline S.No. & Compound & Structure $^{*}$ \\
\hline 1. & Alpha-pinene epoxide & \\
\hline 2. & alpha-fenchyl alcohol & \\
\hline 3. & camphene hydrate & \\
\hline 4. & Borneol & \\
\hline 5 & alpha-humulene & \\
\hline 6 & Trans-caryophyllene & \\
\hline 7. & Ledol & \\
\hline 8 & gamma-eudesmol & \\
\hline
\end{tabular}


empirical formula $\mathrm{C}_{10} \mathrm{H}_{18} \mathrm{O}$ and systematic name 1, 3, 3-trimethyl-2-oxabicyclo [2.2.2] octane. It is sometimes traded commercially as "eucalyptol". Cineole determines the commercial value of the oil and its importance as a raw material for different industries. Different percentages of 1, 8-cineole in E. globulus leaf oil have been reported: $64.5 \%$ in Uruguay, $77 \%$ in Cuba, $86.7 \%$ in California, $58 \%$ to $82 \%$ in Morocco, $48.7 \%$ in Africa, and $50 \%$ to $65 \%$ in Argentina ${ }^{22}$. Alpha-pinene is present in essential oil of all countries but the percentage varies from place to place. Highest percentage of alpha-pinene $(24.60 \%)$ in Algeria followed by Ethiopia (23.79\%). Least \% of alpha-pinene is present in Nigeria (4.16 $\%$ ). Alpha-pinene is a component of many essential oil and has anti-inflammatory and antimicrobial properties $^{24}$.

\section{CONCLUSION}

This study has shown that essential oil of Eucalyptus globulus grown in Dehradun, India possesses rather a good amount of eucalyptol (1,8-Cineole) which determine the commercial value of oil. Beta-eudesmol is present in highest amount in Dehradun essential oil which is absent in all other countries except Ethiopia. Eight components are uniquely present in essential oil of Dehradun. This study has precisely compared essential oil components from Eucalyptus globulus fresh leaves, around the globe. Further, studies with purified major compounds, either as single entities or in combinations would pave way for better understanding of the functionalities associated with various bioactivities.

\section{REFERENCES}

1. Sacchetti, G.; Maietti, S.; Muzzoli, M.; Scaglianti. M.; Manfredini, S.; Radice, M.; Bruni, R. Food Chemistry 2005, 91, 621632.

2. Hassani, A. A.; International Letters of Chemistry, Physics and Astronomy 2013, 9, 17-24.

3. Boukhatem, M. N.; Kameli, A.; Saidi, F. Food Control 2013, 34(1), 208-213.

4. Bremness, L. Herbs. Dorling Kindersley, London, 2000, 54.

5. Baratta, M.T.; Dorman, H. J.; Deans, S. G.; Figueiredo, A. C.; Barroso, J. G.; Ruperto, G. Flavour and Fragrance Journal 1998, 13, 235-244.

6. Edris, E.; Phytotherapy Research 2007, 21(4), 308-323.

7. Bakkali, F.; Averbeck, S.; Idaomar, M. Food and Chemical Toxicology 2008, 46(2), 446475.

8. Bachheti, R. K.; Joshi, A.; Singh, A. International Journal of Chem Tech Research, 2011, 3(2), 625-628.

9. Elaissi, A.; Salah, K. H.; Mabrouk, S.; Larbi, M. K.; Chemli, R.; Skhiri, F. H. Food Chemistry, 2011, 129, 1427-1434.

10. Gilles, M.; Zhao, J.; Agboola, M. An. M. Food Chemistry, 2010, 119, 731-737.

11. Bachheti, R. K. Der Pharma Chemica, 2015,
7(2), 209-214.

12. Marzoug, H. N. B.; Romdhane, M.; Lebrihi, A.; Mathieu, F.; Couderc, F.; Abderraba, M,; Khouja M. L.; Bouajila, J. Molecules, 2011, 16, 1695-1709.

13. Barra, A.; Coroneo, V.; Dessi, S.; Cabras, S.; Angioni, A. Nat Prod Commun. 2010, 5(2), 329-35.

14. Sulaiman, G. M.; Marzoog, T. R.; Mohammed, W. H.; Bagnati, R. American Journal of Agricultural and Biological Sciences, 2014, $9(1), 78-88$.

15. Nasrabadi, M. R.; Pourmortazavi, S. M.; Nazarian, S.; Ahmadi F.; Batooli, International Journal of Food Properties, 2013, 16 (ㅁ), 1080-1091.

16. Madouri, L. H.; Asma, B.; Madani, K.; Ould, Z. B.; Said, Si.; Rigou, P,; Grenier, D.; Allalou, H.; Remini, H.; Adjaoud, A.; Makhlouf. L. B. Industrial Crops and Products, 2015, 78 148-153.

17. Coppen, J. J. CRC Press 2003, 112-145.

18. Sundar, S. S. Forest Development and Eucalyptus controversy in Karnataka, Workshop on Eucalyptus plantation, Indian Statistical Institute, Bangalore. 1984.

19. Joshi, R. K. Aroma profile of Eucalyptus globulus: collected from northwest Karnataka, India Scientific World, 2012, 10, (10), 89-90. 
20. Tyagi, A. K.; Malik, A. Food Chemistry 2011, 126 (1), 228-235.

21. Zira, S. S.; Benjilali, B. B. Journal of Essential Oil Research, 1996, 8, 19-24.

22. Viturro, C. I. Journal of Essential Oil Research, 2003, 15, 206-208.
23. El, M.; Yc, L.; Tsuneki, H.; Xiao, J. F,; Xia M,; Wang M. W,; Kimura. J Asian Nat. Prod. Res., 2008, 10 (1-2): 159-67.

24. http://www.wisegeekhealth.com/what-are-themedical-uses-of-alpha-pinene.htm 